\title{
PENERAPAN MATERIAL FINISHING INTERIOR KAFÉ DI TEMBALANG, SEMARANG
}

\author{
Hieronimus Bimamurti S., Sukawi ST.MT \\ Departemen Arsitektur, Fakultas Teknik, Universitas Diponegoro, \\ Jl. Prof. Soedarto, SH, Kampus Undip Tembalang, Semarang, Indonesia 50275
}

\begin{abstract}
ABSTRAK
Perkembangan kafe sangat dipengaruhi oleh tempat dan pengguna. Kawasan Tembalang di Semarang memiliki daya tarik bagi pengusaha kafe karena terdapat beberapa universitas dimana mahasiswa menjadi pasar utamanya. Dengan kondisi ini beberapa pemilik kafe berusaha untuk menampilkan desain yang berbeda dari interior ruang makan dengan mengembangkan pemakaian material yang ada sebagai dinding, lantai dan langit-langit, serta furniture. Penelitian dilakukan untuk melihat material finishing paling dominan yang pada 7 interior ruang makan kafe di Tembalang. Ke-tujuh kafe tersebut antara lain: Icos Café, Parlour Café, Le Blanc Coffee Shop, Coffee Groove, Golden Brown Café, D'Bims Café dan Trem Coffee.
\end{abstract}

Kata Kunci: Kafe, interior, material.

\section{PENDAHULUAN}

Kafe berasal dari bahasa Prancis, Café yang berarti kopi(minuman) yang kemudian berkembang menjadi tempat untuk menikmati kopi (Wikipedia, 2014). Dalam Kamus Besar Bahasa Indonesia, kafe adalah tempat minum yang pengunjungnya dapat memesam minuman seperti kopi, teh, bir dan kue-kue. Sedangkan menurut Peraturan Menteri Pariwisata Dan Ekonomi Kreatif Republik Indonesia Nomor 10 Tahun 2014 tentang Standar Usaha Kafe, kafe merupakan tempat penyeiaan makanan ringan dan minumam ringan dilengkapi dengan peralatan dan perlengkapan untuk proses pembuatan, penyimpanan dan/atau penyajiannya, didalam

1 tempat tetap yang tidak berpindah-pindah.

Dalam perkembangannya kafe tidak hanya digunakan sebagai tempat menikmati makanan atau minuman namun juga menjadi tempat untuk ajang berkumpul atau berbincang. Hal ini menyebabkan bentuk fisik dari ruang makan kafe berkembang untuk menciptakan suasana yang lebih nyaman bagi pengunjung. Beberapa kafe yang ada bahkan mencoba memanfaatkan kecintaan seseorang terhadap hobi, barang, mahluk hidup, atau suasana tertentu untuk menciptakan suasana nyaman dan unik, seperti "Warung Misbar" di Bandung yang menampilkan film era 70-an di sebuah layar yang diperuntukkan bagi pecinta film jaman dulu, atau "Retro Kafe" di Kota Lama Semarang yang menghadirkan suasana zaman dahulu melalui barang-barang kuno yang ada.

Selain penggunaan tema sebagai pembentuk suasana nyaman, pemilihan material juga dapat memberi andil dalam membentuk suasana nyaman dalam kafe. Banyak bahan material yang dapat digunakan sebagai finishing baik dinding, lantai, maupun langit-langit. Material yang paling sering dijumpai adalah cat. Beberapa orang memilih menggunakan cat karena mudah dalam penerapannya dan memiliki banyak varian warna. Cat paling banyak ditemukan untuk finishing dinding dan langit-langit. Selain cat, bahan yang sering dijumpai lainnya adalah wallpaper, HPL dan vinyl karena tekstur dan pola yang dimiliki ketiga bahan tersebut sulit untuk dapat ditiru oleh material cat. Selain itu, material yang digunakan dalam perabotan juga dapat mendukung dalam membentuk suasana nyaman.

Sehubungan dengan itu, banyak industri kafe yang berkembang di Semarang

dikarenakan banyaknya banyaknya sekolah tinggi yang tersebar berbanding lurus dengan jumlah mahasiswa yang menjadi target pasar utama kafe. Salah satu daerah tersebut adalah Kecamatan Tembalang.

Banyaknya jenis material yang dapat diterapkan baik pada elemen pembentuk ruang yaitu dinding, lantai,dan langit-langit dan perabotan, juga banyaknya café yang terdapat di Tembalang ini mendasari peneliti untuk melihat jenis material apa yang paling 
dominan atau paling banyak digunakan dan diterapkan pada interior ruang makan kafe.

\section{KAJIAN PUSTAKA}

Kafe

Menurut Kamus Besar Bahasa

Indonesia, kafe dapat berarti sebagai tempat minum yang pengunjungnya dapat memesan minuman, seperti kopi,the, bir dan kue-kue atau tempat minum kopi yang pengunjungnya dihibur dengan musik.

Kemudian menurut Peraturan Menteri

Pariwisata dan Ekonomi Kreatif Republik Indonesia Nomor 10 Tahun 2014 tentang Standar Usaha Kafe, kafe adalah sebuah tempat usaha yang menyediakan makanan ringan dan minuman ringan dilengkapi dengan perlengkapan untuk proses pembuatan, penyimpanan dan/atau penyajiannya, di dalam satu tempat tetap yang tidak berpindahpindah. Dalam Wikipedia.com, kafe berasal dari bahasa Perancis, Café yang berarti kopi(minuman) yang kemudian berkembang untuk tempat menikmati minuman yang tidak hanya kopi, namun juga minuman dan makanan ringan lainnya seperti kue, pasta, dan snack

\section{Ruang Interior}

Dalam Kamus Besar Bahasa Indonesia, nterior berarti bagian dalam gedung (ruang dsb). Persepsi ruang interior muncul karena adanya ikatan bidang lantai, dinding, dan

langit-langit yang merupakan elemen-elemen arsitektur yang mendefinisikan pembatan ruang fisik (Ching \& Binggeli, 2011).

Pada umumnya ruang interior dibentuk

oleh sturktur bangunan seperti kolom dan balok, lalu kemudian ditegaskan batasnya oleh dinding, lantai dan langit-langit, yang kemudian ditempatkan elemen pendukung untuk menghubungkan ruang satu dengan ruang lain dan elemen pendukung berupa pengisi seperti furniture.

Menurut Ching \& Binggeli dalam

Desain Interior dengan Ilustrasi, terdapat 3 dimensi keruangan yang menentukan proporsi, skala ruang dan cara penggunaan ruang, antara lain:

a. Dimensi horizontal ruang, lebar.

Terbentuk dari bentang struktur yang berada di ruang tersebut. Lebar ruang interior dibatasi oleh tuntuan struktur. Akan tetapi, lebar tersebut harus ditentukan menurut persyaratan mereka yang menggunakan ruang dan kebutuhannya untuk mengatur batas bagi mereka dan aktivitasnya.

b. Dimensi horizontal ruang, panjang.

Khusus pada ruang persegi, tidak ada perbedaan pada lebar dan panjangnya. Namun ketika panjang ruang lebih besar daripada dua kali lebarnya, ia cenderung mendominasi dan mengendalikan tampilan dan penggunaan ruang.

c. Dimensi vertikal, tinggi.

Pada bagian ini, langit-langit menjadi elemen yang menentukan dimensi vertikal.

Langit-langit yang tinggi sering dihubungkan dengan perasaan kehebatan dan kebesaran. Langit-langit yang rendah sering mengkonotasikan kenyamanan dan keintiman.

\section{METODE PENELITIAN}

Metode penelitian yang digunakan adalah penelitian kualitatif yang menggambarkan masalah secara rinci dari informan/lokasi penelitian dan dirumuskan melalui kata-kata atau narasi.

Pengumpulan data dilakukan dengan cara pengamatan dan dokumentasi langsung pada lokasi penelitian, ditambah dengan wawancara sebagai opsi kedua untuk menambah data.

\section{BATASAN PENELITIAN}

a. Lokasi penelitian adalah kafe di Tembalang, Semarang, sepanjang.

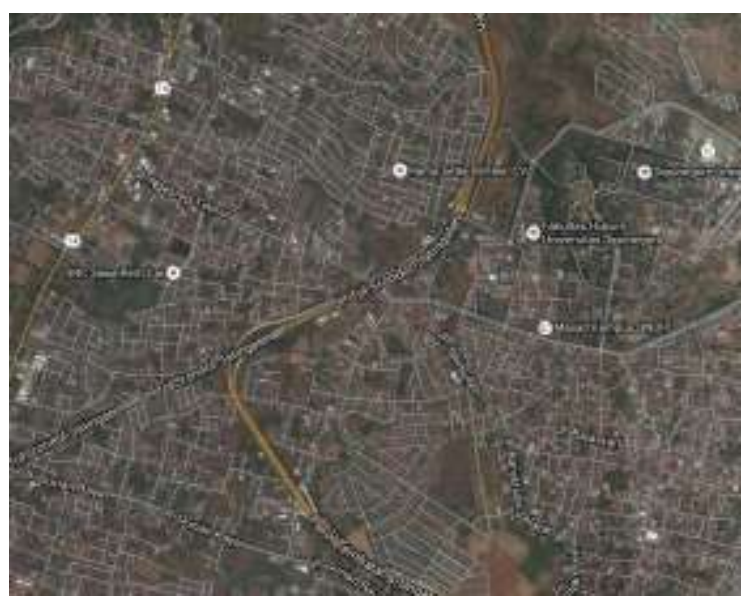

Lokasi penelitian

Kafe yang dijadikan objek berupa ruang tertutup, tidak termasuk kafe dengan ruang semitertutup.

b. Objek penelitian berupa material finishing pada interior ruang makan kafe. 
Pengamatan hanya pada material finishing yang diterapkan pada objek yang diamati. Objek yang diamati berupa dinding, lantai, plafon, perabot berupa meja dan kursi makan yang membentuk tampilan visual interior ruang makan.
HASIL PENELITIAN DAN ANALISA

Tinjauan Objek Penelitian

Terdapat 7 kafe di Tembalang yang dijadikan objek penelitian.

\begin{tabular}{|c|c|c|}
\hline No. & Nama Kafe & Foto \\
\hline 1 & Icos Café & \\
\hline 2 & Parlour Café & \\
\hline 3 & $\begin{array}{l}\text { Le Blanc Coffee } \\
\text { Shop }\end{array}$ & \\
\hline 4 & Coffee Groove & \\
\hline 5 & Golden Brown Café & \\
\hline 6 & D’Bims Café & \\
\hline
\end{tabular}




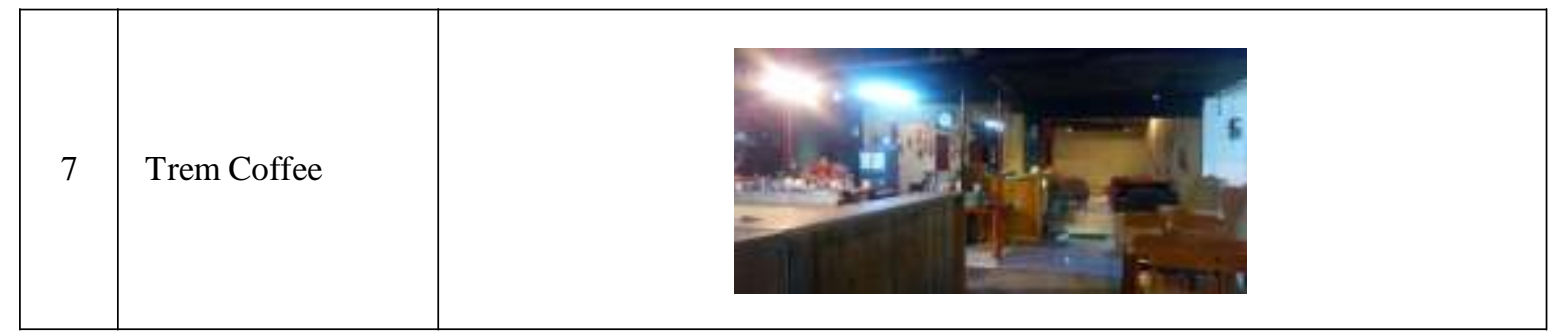

HASIL PENELITIAN

a. Material finishing pada elemen pembentuk ruang

\begin{tabular}{|c|c|c|c|c|c|}
\hline No. & Nama Kafe & $\begin{array}{c}\text { Elemen } \\
\text { Pembentu } \\
\mathbf{k}\end{array}$ & Material & $\%$ & Keterangan Tambahan \\
\hline \multirow{3}{*}{1} & \multirow{3}{*}{ Icos Café } & Dinding & $\begin{array}{l}\text { - Cat } \\
\text { - Wallpaper }\end{array}$ & $\begin{array}{l}50 \\
30\end{array}$ & $\begin{array}{l}\text { Sisa } 20 \% \text { dari luasan } \\
\text { dinding berupa }\end{array}$ \\
\hline & & Lantai & Keramik & 100 & Keramik berwarna coklat \\
\hline & & Langit-langit & $\begin{array}{l}\text { Gipsump - } \\
\text { nutih }\end{array}$ & 100 & - \\
\hline \multirow{3}{*}{2} & \multirow{3}{*}{ Parlour Café } & Dinding & Cat & 70 & $\begin{array}{l}\text { Sisa } 30 \% \text { dari luasan } \\
\text { dinding berupa jaring- }\end{array}$ \\
\hline & & Lantai & Keramik & 100 & Keramik berwarna putih \\
\hline & & Langit-langit & Cat & 100 & $\begin{array}{c}\text { Tanpa plafond, cat } \\
\text { langsung } \\
\text { diterapkan pada balok dan }\end{array}$ \\
\hline \multirow{3}{*}{3} & \multirow{3}{*}{$\begin{array}{l}\text { Le Blanc Coffee } \\
\text { Shop }\end{array}$} & Dinding & Cat & 70 & $\begin{array}{l}\text { Sisa } 30 \% \text { dari luasan } \\
\text { dinding berupa jaring- }\end{array}$ \\
\hline & & Lantai & Keramik & 100 & $\begin{array}{l}\text { Keramik bermotif batu } \\
\text { lempeng dan susunan batu }\end{array}$ \\
\hline & & Langit-langit & - & - & $\begin{array}{c}\text { Tanpa plafond, ekspos rangka } \\
\text { dan atap }\end{array}$ \\
\hline \multirow{3}{*}{4} & \multirow{3}{*}{ Coffee Grove } & Dinding & Cat & 100 & - \\
\hline & & Lantai & Keramik & 100 & Keramik berwarna putih \\
\hline & & Langit-langit & Cat & 100 & Plafond cat coklat muda \\
\hline \multirow{3}{*}{5} & \multirow{3}{*}{ Golden Brown Café } & Dinding & Cat & 80 & $\begin{array}{r}\text { Sisa 20\% dari luasan } \\
\text { dinding berupa }\end{array}$ \\
\hline & & Lantai & $\begin{array}{l}\text { - Keramik } \\
\text { - Kayu }\end{array}$ & $\begin{array}{l}80 \\
20 \\
\end{array}$ & $\begin{array}{l}\text { Keramik berwarna } \\
\text { putih, Lantai kayu untuk }\end{array}$ \\
\hline & & Langit-langit & Cat & 100 & Plafond cat putih \\
\hline \multirow{3}{*}{6} & \multirow{3}{*}{ D'Bims Café } & Dinding & $\begin{array}{l}\text { - Wallpaper } \\
\text { - HPL }\end{array}$ & $\begin{array}{l}40 \\
40 \\
\end{array}$ & $\begin{array}{r}\text { Sisa } 20 \% \text { dari luasan } \\
\text { dinding berupa }\end{array}$ \\
\hline & & Lantai & Keramik & 100 & Keramik berwarna putih \\
\hline & & Langit-langit & Cat & 100 & $\begin{array}{r}\text { Plafond cat putih dan hijau } \\
\text { motif papan catur }\end{array}$ \\
\hline
\end{tabular}




\begin{tabular}{|c|l|l|l|c|c|}
\hline \multirow{2}{*}{7} & \multirow{2}{*}{ Trem Coffee } & Dinding & Cat & 100 & - \\
\cline { 3 - 6 } & Lantai & Keramik & 100 & Keramik berwarna putih \\
\cline { 3 - 6 } & Langit-langit & Cat & 100 & Plafond cat hitam \\
\hline
\end{tabular}

1. Dinding

Dari 7 kafe yang telah diamati, didapatkan 3 material yang digunakan sebagai penutup dinding, antara lain:

- Cat

Terdapat 6 dari 7 kafe(semua kafe kecuali D'bims café) yang menggunakan cat sebagai penutup dinding dan 6 kafe tersebut menggunakan cat diatas $50 \%$ dari seluruh luasan dinding. Berbagai warna digunakan, namun warna putih paling mendominasi dari keseluruhan warna yang digunakan.

- Wallpaper

Hanya ada 2 dari 7 kafe(I Cos Café dan

D’Bims Café) yang menggunakan wallpaper sebagai penutup dinding. Namun tidak ada satupun yang penggunaannya diatas $50 \%$ dari seluruh luasan dinding.

- HPL

Hanya ada 1 kafe(D'Bims Café) yang menggunakan HPL dan penggunaannya hanya sebesar $40 \%$ dari keseluruhan luas dinding yang ada.

2. Lantai

Ditemukan 2 material dari pengamatan yang dilakukan dari 7 kafe yang ada, material tersebut antara lain:

- Keramik

Berbagai macam motif dan warna ditemukan dari pengamatan yang dilakukan, dari keramik berwarna potih polos, motif garis berwarna coklat, hingga bermotif baru lempeng. Namun dalam penggunaannya, seluruh kafe menggunakan keramik sebagai material untuk penutup lantai.

- Kayu

Hanya 1 kafe (Golden Brown Café) yang menggunakan kayu sebagai bahan penutup lantai dan digunakan sebagai panggung.

3. Langit-Langit

Terdapat berbagai macam finishing yang diterapkan pada langit-langit dari 7 kafe yang telah diamati.

- Plafond dengan cat

5 dari 7 kafe(semua kafe kecuali Parlour Café dan Le Blanc Café) menggunakan plafon yang kemudian dicat sebagai material finishing untuk langit-langit. Dan paling dominan menggunakan cat putih sebagai finishing pada plafond.

- Finishing cat tanpa plafond Cat langsung diterapkan pada balok dan beton plat lantai. Hanya ada 1 kafe yang menggunakan cara ini yaitu Parlour Cafe, dan cat yang digunakan menggunakan warna hitam.

- Tanpa finishing Rangka dan penutup atap diekspos atau tanpa menggunakan plafond. Hanya 1 kafe yang menerapkan cara ini yaitu Le Blanc Cafe.

b. Material pada furniture

\begin{tabular}{|c|l|l|l|l|}
\hline No. & \multicolumn{1}{|c|}{ Nama Kafe } & \multicolumn{1}{|c|}{ Furnitur } & Material & Keterangan Tambahan \\
\hline \multirow{2}{*}{1} & \multirow{2}{*}{ Icos Café } & Meja & HPL & - \\
\cline { 3 - 5 } & Kursi & $\begin{array}{l}- \text { Sofa } \\
- \text { Besi }\end{array}$ & - \\
\hline \multirow{2}{*}{2} & Parlour Café & Meja & Kayu & $\begin{array}{c}\text { Finishing melamin, beberapa kursi } \\
\text { dikombinasi dengan besi }\end{array}$ \\
\cline { 3 - 5 } & Kursi & & \\
\hline
\end{tabular}




\begin{tabular}{|c|c|c|c|c|}
\hline \multirow{2}{*}{3} & \multirow{2}{*}{$\begin{array}{l}\text { Le Blanc Coffee } \\
\text { Shop }\end{array}$} & Meja & HPL & - \\
\hline & & Kursi & Besi & $\begin{array}{c}\text { Dikombinasi dengan bahan } \\
\text { kanvas }\end{array}$ \\
\hline \multirow{2}{*}{4} & \multirow{2}{*}{ Coffee Grove } & Meja & \multirow{2}{*}{ Kayu } & \multirow{2}{*}{-} \\
\hline & & Kursi & & \\
\hline \multirow{2}{*}{5} & \multirow{2}{*}{ Golden Brown Café } & Meja & \multirow{2}{*}{ Kayu } & \multirow{2}{*}{-} \\
\hline & & Kursi & & \\
\hline \multirow{2}{*}{6} & \multirow{2}{*}{ D’Bims Café } & Meja & $\begin{array}{l}\text { - Kayu } \\
\text { - Alumunium }\end{array}$ & - \\
\hline & & Kursi & Sofa & - \\
\hline \multirow{2}{*}{6} & \multirow{2}{*}{ Trem Coffee } & Meja & $\begin{array}{l}\text { - Kayu } \\
\text { - Rotan }\end{array}$ & - \\
\hline & & Kursi & $\begin{array}{l}\text { - Sofa } \\
\text { - Rotan }\end{array}$ & - \\
\hline
\end{tabular}

1. Meja

Terdapat 4 material yang diterapkan pada meja makan dari pengamatan yang dilakukan.

- Kayu asli dengan dan tanpa finishing 5 kafe (semua kafe kecuali Icos Café dan Le Blanc Café) menggunakan kayu asli sebagai material meja makan yang ada. Beberapa diantaranya menggunakan finishing berupa melamin dan beberapa lainnya tanpa finishing.

- HPL

Hanya 2 kafe (Icos Café dan Le Blanc Café) yang menggunakan HPL sebagai material penutup untuk meja makan pada ruang makan kafenya.

- Logam (alumunium dan besi)

Terdapat 2 kafe (Icos Café dan Le Blanc Café) yang menggunakan alumunium atau besi untuk material meja makannya.

- Rotan

Rotan yang digunakan berupa anyaman dan ditambahkan kaca sebagai tempat makan. Hanya 1 kafe yang menggunakan

\section{Kursi} material ini yaitu Trem Coffee.

Terdapat 4 material yang diterapkan pada kursi makan dari pengamatan yang dilakukan.

- Sofa

3 dari 7 kafe menggunakan sofa untuk digunakan sebagai kursi makan yaitu
Icos Café, D'Bims Café dan Trem Coffee.

- Kayu asli dengan dan tanpa finishing Sama dengan sofa, 3 dari 7 kafe menggunakan kayu untuk digunakan sebagai kursi makan yaitu Parlour Café, Coffee Grove dan Golden Brown Café. Beberapa diantaranya menambahkan busa/foam untuk landasan duduk dan sebagian tanpa menggunakan foam.

- Besi

2 kafe (Icos Café dan Le Blanc Cafe) menggunakan material besi sebagai kursi. 1 kafe (Icos Café) menambahkan foam/busa sebagai landasan duduk, dan

1 kafe (Le Blanc Café) lainnya menggunakan bahan seperti kanvas sebagai landasan dan sandaran.

- Rotan

Hanya 1 kafe (Trem Coffee) yang menggunakan anyaman rotan sebagai kursi makan.

\section{KESIMPULAN}

Dari analisis yang telah dilakukan berdasarkan data yang didapatkan dari hasil pengamatan, didapatkan beberapa kesimpulan, antara lain:

a. Dilihat dari elemen pembentuk ruang:

1. Material cat menjadi paling dominan atau paling sering digunakan sebagai bahan finishing dinding. Beberapa menambahkan dekorasi berupa 
gambar/sketsa untuk mengurangi monoton. Warna yang paling dominan adalah putih.

2. Plafond dengan finishing cat putih menjadi material yang paling sering digunakan untuk langit-langit.

3. Keramik menjadi material paling dominan berikutnya yang digunakan sebagai penutup lantai dari semua kafe yang ada di tembalang.

b. Dilihat dari furniture(meja dan kursi):

1. Kayu asli baik dengan maupun tanpa finishing menjadi material paling banyak digunakan sebagai meja makan

2. Material untuk kursi memiliki 2 material yang sama-sama paling banyak digunakan, yaitu sofa dan kayu baik dengan maupun tanpa finishing.

\section{DAFTAR PUSTAKA}

Ching, F. D., \& Binggeli, C. (2011). Desain Interior Dengan Ilustrasi. Jakarta: PT Indeks.

Kamus Besar Bahasa Indonesia. (n.d.). Kafe. Retrieved November 12, 2015, from KBBI Online: kbbi.web.id/kafe

Peraturan Menteri Pariwisata dan Ekonomi Kreatif Republik Indonesia Nomor 10 Tahun 2014 Tentang Sandar Usaha Kafe

Wikipedia. (2014, September). Cafe. Retrieved September 22, 2015, from Wikipedia: https://simple.m.wikipedoa.org/wiki/C af\% $3 \%$ A9 